\title{
ANALISIS PELAKSANAAN PROGRAM SISTEM PERTANIAN TERINTEGRASI (SIMANTRI) TERHADAP EKSISTENSI PERTANIAN DI KECAMATAN GEROKGAK KABUPATEN BULELENG
}

\author{
Lina Nur Hayati, I Ketut Suratha, I Putu Sriartha \\ Program Studi Pendidikan Geografi \\ Universitas Pendidikan Ganesha \\ Singaraja, Indonesia
}

e-mail :

\begin{abstract}
Abstrak
Penelitian ini dilaksanakan di Kecamatan Gerokgak dengan tujuan untuk: (1) Mengetahui pelaksanaan program simantri di Kecamatan Gerokgak (2) mengetahui eksistensi pertanian di Kecamatan Gerokgak (3) Menganalisis hubungan pelaksanaan program simantri terhadap eksistensi pertanian di Kecamatan Gerokgak. Penelitian ini dirancang sebagai penelitian deskriptif korelasional dengan menggunakan teknik purposive random sampling. Pengumpulan data menggunakan metode wawancara dan kuesioner, yang selanjutnya dianalisis dengan analisis deskriptif, analisis product moment. Hasil penelitian menunjukkan bahwa (1). Pelaksanaan simantri di Kecamatan Gerokgak secara kelompok maupun secara individu sudah tergolong dalam pelaksanaan yang cukup baik (2). Eksistensi pertanian di Kecamatan Gerokgak mengalami peningkatan setelah adanya program simantri peningkatan tersebut terlihat dari produktivitas tanaman pangan setelah 4-5 tahun berjalannya program simantri (3). Terdapat hubungan yang positif antara pelaksanaan simantri dengan eksistensi pertanian di Kecamatan Gerokgak.
\end{abstract}

Kata kunci: Pelaksanaan, program simantri, eksistensi pertanian 


\section{PENDAHULUAN}

Pertanian merupakan bagian vital yang tidak dapat dipisahkan dari perjalanan panjang pembangunan Indonesia. Pertanian memiliki peran strategis dalam menunjang pembangunan perekonomian nasional karena didukung oleh potensi sumber daya alam yang melimpah. Pertanian menjadi penting karena masyarakat di pedesaan yang dominan sebagai petani sangat tergantung pada kegiatan pertanian. Pemerintah Provinsi Bali dalam upaya mengatasi masalah di pedesaan terutama menyangkut kemiskinan, menciptakan kesempatan kerja dan meningkatkan pendapatan merintis sebuah program yang dinamakan Sistem Pertanian Terintegrasi (SIMANTRI) sejak tahun 2009 (Wibawa dan Yasa, 2013). Adanya Simantri akan mendukung perkembangan diversifikasi usahatani terhadap potensi lokal, penyediaan lapangan kerja, serta integrasi pertanian dan peternakan secara berkelanjutan untuk meningkatkan pendapatan.

Simantri adalah upaya terobosan dalam mempercepat adopsi teknologi pertanian karena merupakan pengembangan model percontohan dalam percepatan alih teknologi kepada masyarakat perdesaan. Menjadikan suatu kawasan sebagai kawasan organik, akan lebih efisien dilakukan dengan model integrasi tanamanternak secara insitu, artinya tanaman-ternak tersebut berada dalam satu kawasan, bahkan dalam satu manajemen (Balai Penelitian Tanaman Pangan Bali, 2011). Sistem ini adalah sistem sustainable atau berkelanjutan karena sumber daya alami tidak dikuras dalam penggunaannya, tetapi diperbaharui secara alami, sehingga melindungi sumber daya tersebut untuk masa depan. Konsep Simantri adalah mengintegrasikan kegiatan sektor pertanian, perkebunan, peternakan dan perikanan dan sektor pendukungnya baik secara vertikal maupun horizontal sesuai potensi masingmasing wilayah dengan mengoptimalkan pemanfaatan sumberdaya lokal yang ada, mengurangi angka kemiskinan dan mengurangi tingkat pengangguran. Inovasi teknologi yang diintroduksikan berorientasi untuk menghasilkan produk pertanian organik dengan pendekatan "pertanian tekno ekologis". Kegiatan integrasi yang dilaksanakan juga berorientasi pada usaha pertanian tanpa limbah (zero waste) dan menghasilkan $4 \mathrm{~F}$ (food, feed, fertilizer dan fuel) (Distan TP Provinsi Bali, 2010).

Guna memaksimalkan produksi pertanian organik dan peternakan secara simultan, maka diperlukan adopsi sistem pertanian terintegrasi. Sistem ini mengintregasikan ternak dengan tanaman dalam satu areal agar bisa mengoptimalkan pemanfaatan lahan yang terbatas. Upaya ini diperlukan dimana lahan pertanian mengalami penyusutan akibat dari meningkatnya alih fungsi lahan. Berdasarkan hal tersebut, Pemerintah Provinsi Bali berfokus pada pembangunan pertanian dengan melaksanakan program Sistem Pertanian Terintegrasi (Simantri) untuk mewujudkan Bali yang Maju, Aman, Damai dan Sejahtera (Bali Mandara) pada tahun 2009 dengan mengadopsi model Prima Tani. Adopsi model Prima Tani cukup beralasan karena ternyata mampu memberikan dampak ekonomi secara signifikan (Dinas Pertanian Tanaman Pangan, 2010).

Simantri yang dilaksanakan sejak tahun 2009 merupakan langkah pemberdayaan potensi pertanian yang dinilai memberikan solusi dalam upaya ikut mendorong peningkatan kesejahteraan petani, mengurangi angka kemiskinan dan mengurangi 
tingkat pengangguran. Simantri mengintegrasikan sektor pertanian, perkebunan, peternakan dan perikanan baik secara vertikal maupun horizontal sesuai dengan potensi masing-masing wilayah. Kabupaten Buleleng merupakan kabupaten yang mendapat paling banyak bantuan Simantri, dimana terdapat 107 Gapoktan dari tahun 2009-2015, perkembangan jumlah simantri yang didapatkan kabupaten Buleleng mengalami peningkatan pada tahuntahun berikutnya. Hal tersebut menunjukkan keseriusan Pemerintah Provinsi Bali dalam membantu masyarakat di bidang pertanian terintregasi untuk meningkatkan pendapatan dan kesejahteraan petani, serta menunjukkan minat, ketertarikan serta antusiasme para petani terhadap pola terintregasi atau Simantri Provinsi Bali. Kecamatan yang paling banyak mendapatkan bantuan simantri adalah kecamatan Gerokgak dimana ada 17 Gapoktan dari tahun 2009-2015.

Namun dalam pelaksanaannya belum semua gapoktan mampu menjalankan program simantri dengan baik dan efisien karena terdapat kendalakendala di lapangan seperti kurang antusiasme para petani dalam melaksanankan Simantri karena masih sangat sulit mengubah pola pikir serta perilaku dan SDM kearah organik dimana masih menerapkan unsur kimiawi. Adanya pola pikir yang hanya menginginkan bantuannya saja tanpa menjalankan kegiatan intregasinya hanya memelihara ternak sapi sapi saja, hal ini dikarenakan kelompok tani pelaksana simantri belum sepenuhnya mengerti tentang tanggung jawab pelaksana simantri berkelanjutan.

Masih adanya pemberitaan di media masa mengenai Program Simantri yang tidak berjalan ataupun tidak tepat sasaran dan untuk keberlanjutan seperti sapi yang tidak bisa beranak, kurus, maupun alatalat yang rusak karena tidak terpakai, Serta tidak adanya peningkatan dalam pertanian. Dengan adanya pemberitaan seperti itu, hendaknya diperlukan suatu analisis terhadap pelaksanaan program Simantri. Analisis yang diperlukan adalah analisis mengenai pelaksanaan program Simantri terhadap eksistensi pertanian di Kecamatan Gerokgak Kabupaten Buleleng.

\section{METODE}

Penelitian ini menggunakan rancangan penelitian deskriptif korelasional. Pendekatan yang digunakan dalam penelitian ini adalah pendekatan keruangan. Populasi dalam penelitian ini adalah seluruh Gapoktan simantri di Kecamatan Gerokgak sampel dalam penelitian ini ditentukan dengan purposive sampling dipilih dengan sengaja 6 Gapoktan simantri yang bisa mewakili seluruh Gapoktan simantri dan disetiap anggota ditentukan dengan simple random sampling diambil 12 orang di setiap Gapoktan simantri. Data primer dan data sekunder yang digunakan dalam penelitian ini dikumpulkan dengan teknik pengumpulan data berupa observasi, wawancara tersruktur, kuesioner, studi pustaka dan pencatatan dokumen. Data dianalisis dengan menggunakan analisis Product Moment.

\section{HASIL DAN PEMBAHASAN}

Kecamatan Gerokgak merupakan salah satu Kecamatan yang terletak di Kabupaten Buleleng. Berdasarkan Letak Astronomisnya Kecamatan Gerokgak terletak antara $114^{0} 25^{\prime} 53^{\prime \prime}$ BT sampai 114052'59" BT dan $8^{\circ} 5^{\prime} 29^{\prime \prime}$ LS sampai $8^{0} 15^{\prime} 31$ 'LS dengan batas selatan Kabupaten Jembrana, batas barat Selat Bali, batas utara Laut Bali, dan batas timur Kecamatan Seririt. Kecamatan Gerokgak 356,57 Km², 
Kecamatan Gerokgak terdiri atas 14 Desa/Kelurahan yakni Sumber Klampok, Pejarakan, Sumber Kima, Pemuteran, Banyupoh, Penyabangan, Musi, Sanggalangit, Gerokgak, Patas, Pengulon, Tingatinga, Celukan Bawang, Tukad Sumaga. (BPS Kabupaten Buleleng, 2016). Topografi kecamatan Gerokgak sangat fluktuatif dari dataran rendah yang berada sepanjang pantai sampai daerah pegunungan.

Kecamatan Gerokgak memiliki wilayah dengan ketinggian sampai 500 m dpl seluas 298,79 km2; wilayah dengan ketinggian 500-1000 mdpl seluas $55,43 \mathrm{~km} 2$ dan wilayah dengan ketinggian lebih dari $1000 \mathrm{~m}$ $\mathrm{dpl}$ seluas $23,5 \mathrm{~km} 2$. Wilayah dengan kemiringan tanah landai (0-25\%) seluas 12.219,25 Ha dan dengan kemiringan miring (25-40\%) seluas $73,12 \mathrm{Ha}$. Jenis tanah yang terdapat di Kecamatan Gerokgak yaitu jenis tanah aluvial dan tanah regosol.

\section{Pelaksanaan Sistem Pertanian Terintegrasi (simantri) di Kecamatan Gerokgak}

Berdasarkan hasil observasi yang sudah dilakukan sehingga didapatkan hasil sebagai berikut dengan Indikator yang digunakan dalam menentukan pelaksanaan simantri yaitu bantuan dana dari pemerintah, pengembangan komoditi tanaman pangan, pengembangan ternak sapi atau kambing, bangunan dan kandang hewan, peralatan kegiatan simantri, peningkatan luas tanam, peralatan kegiatan simantri, meningkatnya efisiensi usaha tani melalui pupuk dan bio pestisida.

$$
\text { Pelaksanaan simantri }
$$

merupakan semua aktivitas, adanya aksi, tindakan, atau mekanisme dalam program simantri. Yang mana dalam kegiatannya melibatkan beberapa unsur dengan usahausaha dan didukung oleh alat-alat penunjang yang dilakukan oleh para gapoktan simantri di Kecamatan Gerokgak. Berdasarkan hasil penelitian dan pemaparan dapat diketahui bahwa pelaksanaan program simantri di Kecamatan Gerokgak secara kelompok sudah tergolong cukup baik namun dari keenam Gapoktan tersebut mempunyai hasil yang berbeda-beda dapat diketahui dari hasil observasi bahwa Gapoktan Bina Karya Bakti Desa Musi paling baik dalam melaksanakan program simantri, lalu yang kedua Sawitra Werdi Karya, yang ketiga pada Gapoktan Yasa Kerti dan Asta Sawitra Tani, yang yang terakhir ada Gapoktan Asta Kusuma Sari dan Gapoktan Wahyu Karya Tani. Perbedaan hasil pelaksanaan tersebut terlihat dari hasil penelitian yang sudah dilakukan pada Gapoktan Bina Karya bakti dan Sawitra Werdi Karya mempunyai hasil yang tidak jauh berbeda hal ini dikarenakan pada kedua Gapoktan tersebut sudah menjalankan hampir seluruhnya kegiatan simantri seperti apa yang diintruksikan oleh pendamping simantri, kedua Gapoktan juga mempunyai jadwal tetap untuk melaksanakan kegiatankegiatan simantri setip harinya, siapa-siapa saja yang pada hari itu dan hari selanjutnya melakukan kegiatan simantri sehingga kegiatan simantri bisa berjalan dengan baik tanpa mengganggu aktivitas maupun pekerjaan lain para anggota simantri, namun perbedaan hasil pupuk dan jumlah hewan ternak terlihat perbedaannya pada Gapoktan Bina Karya Bakti bisa menghasilkan pupuk yang lebih banyak dari Gapoktan Sawitra Werdi Karya ini karena jumlah hewan ternak yang dimiliki berbeda sehingga kotoran ternak yang dihasilkan berbeda meskipun alat yang digunakan sama.

Gapoktan Bina Karya Bakti dengan gapoktan Yasa Kerti kedua Gapoktan tersebut sudah terlihat perbedaan hasil pelaksanaan simantrinya pada Gapoktan Bina 
Karya Bakti sudah berjalan dengan baik namun berbeda dengan Gapoktan Yasa Kerti yang belum berjalan dengan baik seperti Gapoktan Bina Karya Bakti pada Gapoktan Yasa Kerti sudah ada jadwal untuk melaksanakan kegiatan simantri namun para anggota belum banyak yang mengikuti jadwal tersebut sehingga kegiatan simantri belum berjalan dengan baik, ternak juga belum berkembang biak seluruhnya sehingga belum bisa menghasilkan pupuk yang banyak karena limbah kotoran sapi yang tidak banyak pula, penguasaan alatalat untuk kegiatan simantri juga sudah mampu dilakukan oleh anggota Gapoktan meskipun belum semua anggota Gapoktan menguasai penggunaan alat tersebut seperti alat pembuat pupuk belum semua anggota menguasai sehingga hanya beberapa yang mampu membuat pupuk berbeda dengan anggota Gapoktan Bina Karya Bakti yang sudah semua anggotanya mampu menggunakan alat-alat simantri sehingga tidak ada kendala untuk membuat pupuk tanpa menunggu anggota yang lain.

Pada Gapoktan Bina Karya Bakti dan Asta Sawitra Tani terlihat dengan jelas perbedaannya dari Gapoktan Bina Karya Bakti yang sudah berjalan dengan baik pelaksanaan simantrinya dengan Gapoktan Asta Sawitra Tani yang belum berjalan dengan baik hal ini terlihat dari hasil ternak yang sudah berkembang biak pada Gapoktan Bina Karya Bakti hampir 100\% sudah berkembang biak namun pada Gapoktan asta Sawitra Tani belum mencapai itu hanya 31 ekor jumlahnya sedangkan Gapoktan Bina Karya Bakti sudah 38 ekor ternak hal ini dipengaruhi oleh tidak adanya jadwal kegiatan untuk melakukan kegiatan simantri termasuk mengurus hewan ternak, sehingga limbah kotoran ternak yang didapat hanya sedikit dan hanya bisa mernghasilkan pupuk yang tidak banyak setiap tahunnya.

Perbedaan hasil pelaksanaan juga terlihat pada Gapoktan Bina Karya Bakti dengan gapoktan Asta Kusuma Sari, perbedaannya sangat jelas terlihat hal ini karena pada Gapoktan Asta Kusuma Sari belum berjalan dengan baik Kegiatan simantrinya oleh anggota Gapoktan. Anggota Gapoktan simantri lebih banyak yang bekerja sendiri-sendiri menjalankan aktivitasnya sehingga kegiatan simantri menjadi tidak terlaksana dengan baik, ternak yang dimiliki sudah berkembang biak namun hanya sebagian saja sehingga tidak menghasilkan limbah kotoran sapi yang banyak bahkan ada limbah yang tidak diproses menjadi pupuk sehingga pupuk yang dihasilkan oleh Gapoktan Asta Kusuma Sari tidak sebanyak pupuk yang dihasilkan oleh Gapoktan Bina Karya Bakti selain itu penguasaan alat kegiatan simantri oleh anggota Gapoktan asta Kusuma Sari juga belum sepenuhnya dikuasai yang menyebabkan banyak anggota yang tidak mengikuti kegiatan simantri.

Pada Gapoktan Wahyu Karya Tani hampir memiliki keadaan yang sama dengan Gapoktan Asta Kusuma Sari, hewan ternak yang dimiliki belum sepenuhnya berkembang biak karena kurangnya pemeliharaan yang baik dari anggota Gapoktan simantri sehingga kotoran sapi yang dihasilkan tidak terlalu banyak dan hanya sedikit yang diproses menjadi pupuk karena anggota Gapoktan kurang memperhatikan keberlanjutan program simantri bahkan peralatan yang dimiliki banyak yang rusak akibat tidak terpakai. Kandang hewan juga tidak terawat dengan baik nampak banyak sekali kotoran hewan yang belum dibersihkan hal ini sangat berbeda dengan Gapoktan Bina Karya Bakti yang sudah berjalan baik pelaksanaan simantrinya karena aggotanya yang selalu melakukan 
kegiatan simantri dengan tepat dan terjadwal dengan teratur.

\section{Eksistensi Pertanian di Kecamatan Gerokgak}

Eksistensi pertanian yang diukur dengan dua indikator yaitu luas lahan tanam dan juga hasil produksi (Produktivitas). Untuk mendapatkan hasil produktivitas makan diperlukan adanya perhitungan dengan cara hasil produksi dibagi dengan luas lahan disetiap gapoktan simantri sehingga akan mendapatkan hasil produktivitas pertanian.

Eksistensi pertanian yang diukur dengan dua indikator yaitu luas lahan tanam dan juga hasil produksi (Produktivitas). Untuk mendapatkan hasil produktivitas makan diperlukan adanya perhitungan dengan cara hasil produksi dibagi dengan luas lahan disetiap gapoktan simantri sehingga akan mendapatkan hasil produktivitas pertanian.

luas lahan tanam rata-rata mengalami peningkatan disetiap gapoktan simantri pada rentang waktu 4 sampai 5 tahun berjalannya program simantri, produksi tanaman pangan mengalami peningkatan disetiap gapoktan simantri pada rentang waktu 4 sampai 5 tahun berjalannya program simantri produksi tanaman pangan yang dikelola oleh gapoktan mengalami peningkatan. Produktivitas tanaman pangan mengalami peningkatan disetiap gapoktan simantri dari awal berdinya simantri sampai pada tahun 2016 pada rentan waktu 4 sampai 5 tahun berjalannya program simantri produktivitas tanaman pangan yang dikelola oleh gapoktan mengalami peningkatan.

Program simantri lebih
terfokus pada pengembangan
tanaman pangan yang bertujuan
untuk mencukupi kebutuhan pangan

dan kemakmuran para petani di perdesaan, di Kecamatan Gerokgak pengembangan tanaman pangan ada 4 jenis yaitu Padi, jagung, kacang tanah, dan kedelai. Eksistensi pertanian diukur dengan 2 indikator luas lahan dan jumlah produksi (produktivitas).

Berdasaran hasil observasi dapat diinformasikan bahwa eksistensi pertanian di Kecamatan Gerokgak pada setiap kelompok simantri, sejak dimulainya pelaksanaan simantri sampai rentang waktu 4 sampai 5 tahun berjalannya program simantri eksistensi pertanian di setiap Gapoktan simantri mengalami peningkatan dari luas lahan, produksi maupun pada produktivitas pertaniannya, meskipun tidak pada setiap jenis pertanian tanaman pangannya mengalami peningkatan. Peningkatan luas lahan tanam disetiap gapoktan simantri di Kecamatan Gerokgak karena masyarakat maupun anggota gapoktan simantri semenjak adanya simantri mereka mempunyai ketertarikan menggunakan lahan yang semula bukan lahan pertanian kemudian dialih fungsikan menjadi lahan tanam untuk pertanian dari program simantri mereka mendapatkan lebih banyak ilmu tentang pertanian sehingga para petani lebih bisa mengolah lahan pertanian mereka dengan tanamantanaman yang cocok ditanam dilahan yang mereka miliki.

Produksi pertanian disetiap gapoktan mengalami peningkatan hal ini dipengaruhi oleh ketersediaan pupuk dan air yang menunjang pertumbuhan tanaman pangan, dengan adanya simantri yang menghasilkan pupuk organik dan bio pestisida turut memberikan kontribusi dalam pertanian di Kecamatan Gerokgak, dengan adanya simantri para petani anggota gapoktan simantri bisa dengan mudah mendapatkan pupuk untuk pertaniannya bahkan dengan 
menggunakan pupuk organik yang dihasilkan oleh gapoktan simantri dirasakan para petani dapat menghilangkan beberapa hama yang biasanya menyerang tanaman pertanian mereka. Dengan adanya pupuk dari program simantri turut menekan biaya produksi karena para petani tidak perlu membeli pupuk untuk tanaman pertanian mereka, meskipun masih membutuhkan pupuk kimia namun penggunaan pupuk kimia tersebut tidak sebanyak dulu sebelum mendapatkan pupuk dari simantri.

Lahan pertanian yang digarap oleh para anggota gapoktan simantri merupakan lahan pertanian milik sendiri karena salah satu persyaratan yang harus dimiliki oleh anggota simantri ialah memiliki lahan pertanian sendiri yang luasnya maksimal 2 ha. Lahan pertanian di kecamatan Gerokgak sebagian besar merupakan lahan kering tanaman yang ditanampun disesuaikan dengan keadaan lahan yang ada. Tanaman yang paling banyak ditanam adalah jagung karena jagung tidak membutuhkan air yang banyak untuk pertumbuhannya.

Kendala yang dihadapi dalam pertanian di Kecamatan Gerokgak ialah ketersediaan air yang sangat kurang dalam mencukupi kebutuhan air untuk lahan pertanian yang menyebabkan pertumbuhan tanaman pertanian kurang maksimal, meskipun pemerintah Kabupaten Buleleng sudah membangun sumursumur guna mencukupi kebutuhan air untuk pertanian mereka. Kendala juga terdapat pada bibit tanaman para anggota gapoktan simantri pada mulanya mendapatkan bibit yang berkualitas dari pemerintah namun setelah 2 kali mendapatkan bibit dari pemerintah para petani anggota gapoktan simantri sudah tidak mendapatkan bibit lagi sampai saat ini sehingga para petani hanya mengandalkan bibit yang mereka tanam sendiri dari hasil panen sebelumnya yang mereka jadikan bibit untuk masa tanam selanjutnya.

\section{Hubungan Pelaksanaan Program Simantri Terhadap Eksistensi Pertanian di Kecamatan Gerokgak}

Pelaksanaan program simantri di Kecamatan Gerokgak yang sudah dilakukan oleh Gapoktan simantri tergolong cukup baik dalam melaksanakan program simantri, hal ini terbukti dari hasil penelitian bahwa program simantri yang ada di kecamatan Gerokgak sudah ada yang berjalan baik namun juga ada yang masih berjalan belum baik. Hasil dari pelaksanaan simantri yang sudah cukup baik tersebut ikut mempengaruhi eksistensi pertanian di Kecamatan Gerokgak, dengan adanya program simantri yang mempengaruhi eksistensi pertanian di Kecamatan Gerokgak, eksistensi pertanian yang diukur dengan indikator luas lahan tanam dan hasil produksi tersebut juga ikut meningkat seiring berjalannya pelaksanaan simantri di Kecamatan Gerokgak. Pelaksanaan simantri yang baik akan mempengaruhi eksistensi dengan baik pula namun meskipun ada pelaksanaan simantri yang belum baik sudah mempengaruhi eksistensi pertanian meskipun eksistensinya belum meningkat dengan baik. Namun secara keseluruhan dengan adanya program simantri yang di lakukan pemerintah Provinsi Bali untuk memberikan kemakmuran kepada para petani sudah hampir berhasil karena dengan adanya program simantri yang sudah mampu meningkatkan eksistensi pertanian di Kecamatan Gerokgak.

Berdasarkan hasil dari uji korelasi tersebut terlihat bahwa nilai signifikan 0,011. Nilai signifikan kurang dari 0,05 yang berarti bahwa terdapat hubungan antara pelaksanaan simantri di Kecamatan Gerokgak terhadap eksistensi pertanian di Kecamatan Gerokgak, dapat dilihat pula nilai koefisien 
korelasi sebesar 0,296 bernilai positif, sehingga hubungan pelaksanaan simantri dan eksistensi pertanian merupakan hubungan yang positif. Jika pelaksanaan program simantri sudah berjalan dengan baik maka eksistensi pertanian juga akan ikut meningkat seiring dengan berjalannya program simantri.

Pada perhitungan yang dilakukan secara manual dengan rumus product moment mendapatkan hasil yang sama seperti perhitungan yang dilakukan dengan menggunakan SPSS 22.0 for windows bahwa terdapatnya hubungan antara pelaksanaan program simantri terhadap eksistensi pertanian di Kecamatan Gerokgak.

\section{SIMPULAN DAN SARAN}

Berdasarkan pembahasan di atas, maka simpulan yang dapat ditarik diantaranya (1) Pelaksanaan simantri di Kecamatan Gerokgak secara kelompok maupun secara individu sudah tergolong cukup baik, hal ini terbukti dari sudah berhasilnya gapoktan memproduksi pupuk organik untuk pertanian dan juga berhasilnya Gapoktan mengembang biakkan hewan ternak yang mereka miliki yang mulanya hanya 20 ekor sudah berkembang biak menjadi 3740 ekor hewan ternak. Kegiatankegiatan simantri juga sudah dilakukan dengan rutin oleh para anggota simantri, kandang hewan sudah terjaga kebersihannya, adanya peningkatan produktivitas pertanian. (2) Eksistensi pertanian di Kecamatan Gerokgak pada setiap kelompok simantri, sejak dimulainya pelaksanaan simantri sampai 5 tahun berjalannya kegiatan simantri eksistensi pertanian di setiap Gapoktan simantri mengalami peningkatan pada produktivitas pertaniannya disetiap komoditi tanaman pangannya. Eksistensi pertanian pada setiap individu yang menjadi anggota simantri juga mengalami peningkatan pada produktivitasnya, produktivitas pertanian di Kecamatan Gerokgak dipengaruhi oleh ketersediaan pupuk dan air yang menunjang pertumbuhan tanaman pangan, dengan adanya simantri yang menghasilkan pupuk organik dan bio pestisida turut memberikan kontribusi dalam pertanian di Kecamatan Gerokgak. (3) Adanya hubungan yang positif antara pelaksanaan program simantri terhadap eksistensi pertanian di Kecamatan Gerokgak. Dengan berjalannya pelaksanaan simantri yang sudah cukup baik mempunyai pengaruh yang positif terhadap eksistensi pertanian.

Saran yang disampaikan oleh peneliti yaitu. (1) Gapoktan simantri yang belum berjalan dengan baik dalam menjalankan pelaksanaan simantri diharapkan dapat merencanakan untuk segera menjalankan kegiatan simantrinya agar bisa berjalan dengan baik seperti halnya Gapoktan simantri yang sudah berjalan dengan baik dan diharapkan agar pemerintah lebih memberikan perhatian terhadap Gapoktan simantri yang belum berjalan dengan baik agar dana yang sudah dikeluarkan oleh pemerintah tidak terpakai dengan percuma.

(2) Untuk para anggota Gapoktan yang belum mengikuti kegiatan programn simantri dengan rutin diharapkan agar mempunyai kesadaran untuk mengikuti kegiatakegiatan program simantri karena hal tersebut juga akan membawa manfaat yang baik untuk para anggota Gapoktan itu sendiri.

\section{UCAPAN TERIMA KASIH}

Penelitian ini dapat diselesaikan berkat bimbingan dari berbagai pihak. Untuk ini pada kesempatan ini diucapkan terima kasih yang setulus-tulusnya kepada Rektor Universitas Pendidikan Ganesha, Dekan Fakultas Hukum dan IImu Sosial, Ketua Jurusan 
Pendidikan Geografi, staff dosen dii Jurusan Pendidikan Geografi, Pembimbing Akademik, Pembimbing 1, Pembimbing 2, Penguji 2, dan Penguji 3, Dinas-dinas pemerintahan di Kab. Buleleng, Gapoktan simantri Kecamatan Gerokgak, Bapak Kepala Gapoktan simantri Kecamatan Gerokgak, situs internet penyedia data (BMKG, BPS) dan rekan-rekan mahasiswa Jurusan Pendidikan Geografi angkatan 2013.

\section{DAFTAR PUSTAKA}

Ashari,S. 2006. Hortikultura Aspek Budidaya. Buku. Jakarta: Universitas Indonesia.

Bagus, Ngurah A.A, 2016. Pengaruh karakteristi petani dan peran pendamping terhadap keberhasilan simantri di Kabupaten Badung. E-Jurnal Ekonomi dan Bisnis Universitas Udayana 5.4 (2016) : 689-720

Badan Pusat Statistik Kabuapaten Buleleng, 2016.Gerokgak dalam angka2016. Buleleng.

BPTP Bali, 2011. Menelisik masa depan sapi potong di Bali. Dalam: FGD BPTP Bali. Denpasar (Indonesia): BPTP Bali

Departemen Pertanian, 2007. Peraturan Menteri Pertanian Nomor 273/Kpts/OT.160/4/2007

Tentang Pedoman Pembinaan Kelembagaan Petani.

Dinas Pertanian Tanaman Pangan Provinsi Bali, 2010. Kebijakan Pengembangan Sarana Tanaman Pangan. Dinas Pertanian Tanaman Pangan Provinsi Bali.
-------, 2010. Sistem Pertanian Terintregasi Provinsi Bali. Denpasar

Made astawa, Ida Bagus. 2012. Buku ajar Statistik Terapan. Jurusan Pendidikan Geografi Fakultas Ilmu Sosial, Universitas Pendidikan Ganesha: Singaraja. Mugnisjah, W. Q. dan A. Setiawan.2001. Produksi Benih. Bumi Aksara. Jakarta

Wibawa, IK.T. dan IN.M. Yasa. 2013. Efektivitas dan Dampak Program Simantri terhadap Pendapatan dan Kesempatan Kerja Rumah Tangga Petani di Desa Kelating Kecamatan Kerambitan Kabupaten Tabanan. E-Jurnal EP Unud 2(6): 314-324. 